Maria Przybyszewska, Barbara Wasiewicz, Ryszard W. Gryglewski

Katedra Historii Medycyny UJ CM

Kraków

\title{
WSPÓŁPRACA EDWARDA SCHUNCKA Z LEONEM MARCHLEWSKIM W ŚWIETLE ZACHOWANEJ KORESPONDENCJI
}

\author{
Leon Marchlewski, Edward Schunck and research into chlorophyll
}

Edward Schunk and Leon Marchlewski were to play a decisive part in the history of research on chemistry of chlorophyll and its derivatives. During only a few-year stay of Marchlewski in the Schunck laboratories in Kersal outside Manchester, a groundbreaking invention in the history of biochemistry took place: the close chemical relationship on the level of chlorophyll derivatives and haemoglobin was revealed. Also then, despite a considerable age difference between them, Schunk, who was at the end of his scientific career and Marchlewski just at the start, they became close friends.

On the basis of the collection of original Schunk's letters to Marchlewski, written in the years 1889-1902, we tried to reconstruct the character of their relationship in science, confronting topics raised in the letters with works published at the time. We sought to establish whether Schunk could have been inspired by research of his Polish colleague and, in turn, if remarks and suggestions of the Englishman could have influenced Marchlewski's research programme. For better understanding the field of research of both scientists, we also shortly described the state of knowledge on chlorophylls and their derivatives at the turn of the $19^{\text {th }}$ and $20^{\text {th }}$ centuries.

Keywords: chlorophyll, history of biochemistry, Leon Marchlewski, Edward Schunck

Słowa kluczowe: chlorofil, historia biochemii, Leon Marchlewski, Edward Schunck

\section{Wstęp}

Badania nad barwnikami świata roślinnego i zwierzęcego stały u podstaw rodzącej się z wolna w XIX wieku chemii organicznej, a także jej młodszej siostry biochemii określanej wówczas bądź to chemią fizjologiczną lub chemią lekarską. 
Znaczący, by nie powiedzieć, że niekiedy decydujący w tym udział mieli również polscy uczeni. Do ścisłej światowej czołówki badaczy zajmujących się tą problematyką zaliczyć należy Leona Marchlewskiego i Marcelego Nenckiego. Ich odkrycia pozwoliły w znaczący sposób wyjaśnić zjawisko ścisłego, chemicznego pokrewieństwa pomiędzy pochodnymi chlorofilu i hemoglobiny, otwierając tym samym nowy rozdział w historii nauk przyrodniczych.

W naszym artykule poświęcamy uwagę zaledwie wycinkowi historii tych badań, które zostawiły swój ślad nie tylko w opublikowanych wynikach, lecz także w prywatnych listach mistrza i współpracownika Leona Marchlewskiego, angielskiego chemika Edwarda Schunka. To właśnie w Kersal pod Manchesterem młody wówczas polski uczony zdobywał pierwsze szlify pod okiem Schuncka. Paroletni pobyt Marchlewskiego na Wyspach Brytyjskich zadecydował o jego dalszym życiu naukowym, i jak wynika z analizowanej przez nas korespondencji, to właśnie wówczas obaj uczeni zadzierzgnęli więzy, jeśli nie przyjaźni, to bliskiego koleżeństwa. Mimo, że Marchlewski w 1897 r. opuścił laboratorium w Kersal i przeniósł się do pracowni badawczej firmy Claus i Ree' w Clayton pod Manchesterem zachowywał wciąż żywy kontakt z Schunckiem. Wzajemne relacje pomiędzy uczonymi utrzymały się również po 1900 r., kiedy to Marchlewski powrócił na stałe do Polski.

Dzięki uprzejmości rodziny Leona Marchlewskiego do zbiorów Katedry Historii Medycyny UJ CM w 2016 r. trafił zbiór fotografii i dokumentów związanych z jego osobą. Wśród nich wyodrębniliśmy zespół kilkunastu listów napisanych, jak już wspomniano powyżej, przez Edwarda Schuncka do Leona Marchlewskiego. Niestety nie udało nam się ustalić, czy zachowała się korespondencja zwrotna, co niewątpliwie zubaża naszą wiedzę o poruszanej przez obu badaczy tematyce. Niemniej jednak uznaliśmy, że warto przedstawić ten niepełny obraz relacji uczonych pracujących nad żywo ich interesującymi wówczas problemami. Jednocześnie podjęliśmy się próby zestawienia treści zachowanej korespondencji z przebiegiem prac badawczych, starając się określić na ile są one ze sobą zbieżne.

Listy, którymi dysponujemy, zostały napisane w okresie od stycznia 1899 r., a więc gdy Marchlewski był jeszcze w Clayton, do listopada 1902 r., gdy Marchlewski pracował już w Krakowie. W 1900 r. bowiem objął po Stanisławie Bądzyńskim (1862-1929) stanowisko kierownika Zakładu Badań Środków Spożywczych w Krakowie. Listów jest w sumie 15 . Wszystkie napisano na papeterii z charakterystycznym nadrukiem w ciemnym tuszu umieszczonym w prawym górnym rogu: KERSAL, MANCHESTER. Wszystkie też spisane były jedną ręką, czarnym atramentem i noszą na końcu autografy Edwarda Schuncka. Charakter pisma sprawia, że niekiedy istnieją trudności z odczytaniem pojedynczych wyrazów, jakkolwiek zazwyczaj nie ma większych problemów ze śledzeniem zawartych w nich treści. Fizyczny stan zachowania papieru należy uznać za bardzo dobry. Każdy z analizowanych przez nas listów jest kompletny. Najdłuższy z nich ma cztery strony, pozostałe około trzech. 
Informacje i opinie są zazwyczaj krótkie, góra parozdaniowe. W wielu przypadkach, zwłaszcza gdy chodzi o nazwy własne badanych związków, Schunk podaje je w formie skrótów, co niekiedy poważnie utrudnia ich identyfikację. Prawie nigdy nie posługuje się wzorami sumarycznymi. Obok informacji dotyczących badań własnych Schuncka bądź też opinii przez niego wyrażanych, jak wynika z kontekstu, w odpowiedzi na relacje przekazane mu przez Marchlewskiego, nierzadko spotykaliśmy się z osądem, niemal zawsze krytycznym, co do wyników prac podejmowanych przez innych badaczy. Prócz spraw czysto naukowych w listach pojawiają się również wątki osobiste. Są one coraz częściej obecne zwłaszcza w korespondencji z lat 1901-1902 r., co miało ścisły związek z pogarszającym się stanem zdrowia Schuncka. Angielski badacz odnosił się również do trosk, jakie miał Marchlewski w Krakowie.

Jak wnosimy na podstawie przeprowadzonej przez nas analizy treści listów Schuncka w korespondencji pomiędzy nim a Marchlewskim wśród problemów naukowych, które zaprzątały obu badaczy, szczególne miejsce zajmują dwa zagadnienia; badania nad chlorofilem i jego pochodnymi oraz nad indygo. Dlatego też za uzasadnione wydaje nam się nieco szersze nakreślenie stanu wiedzy o chemii chlorofilu oraz chemii indygo na przełomie XIX i XX wieku.

\section{Stan wiedzy o chlorofilu na przełomie XIX i XX wieku}

Od czasu, gdy badania Jeana Senebier'a (1742-1809) i Nicolasa-Theodore Sausure’a (1767-1845), wykazały, że tylko zielone organy roślin są w stanie asymilować tj. przemieniać dwutlenek węgla i wodę pod wpływem światła w materię organiczną, zielony barwnik stał się przedmiotem licznych studiów naukowych. Pracowali nad nim anatomowie, fizjologowie, fizycy i chemicy ${ }^{1}$.

Niemiecki botanik, profesor uniwersytetów w Bernie i Tybindze, Hugon von Mohl (1805-1872), który w dziedzinie anatomii roślin położył znaczące zasługi, przeprowadzając m.in. klasyfikację tkanek roślinnych na podstawie genezy ich powstawania. Był pierwszym, który wyodrębnił chloroplasty w komórkach roślin. Opisał charakterystyczne skupiska barwnika w komórkach roślinnych, które określił mianem Chlorophpyllkörnern ${ }^{2}$. Obserwacje tego uczonego, dopełnione zostały później przez innego botanika Juliusa von Sachs'a (1832-1897), autora opisu procesu powstawania skrobi w chloroplastach w obecności dwutlenku węgla.

Równolegle z badaniami botaników, postępowały prace chemików i fizyków. Od czasu, gdy francuski badacz Hilaire Marin Rouelle (1718-1779) udowodnił rozpuszczalność zielonego barwnika w alkoholu, badania struktury chemicznej chlorofilu nabrały rozpędu, chociaż wiele z nich nie przyniosło początkowo jednoznacznych

1 L. Marchlews ki: Chemija chlorofilu, „Wiadomości Farmaceutyczne” R. 21: 1894 nr 2, s. 27.

2 G. D. Krogmann: Discoveries in Oxygenic Photosynthesis (1727-2003): A Perspective, „Photosynthesis Research” t. 80: 2004, s. 19. 
rezultatów. Jednym z najważniejszych narzędzi w badaniach chlorofilu i jego pochodnych stał się w XIX w. spektroskop, którego budowa stopniowo rozwijana od pierwszych dekad tego stulecia znalazła swoje rozwiązanie w konstrukcji będącej plonem prac prowadzonych w latach 1860. przez fizyka Gustava Kirchhoffa (18241887) i chemika Roberta Bunsena (1811-1899)³. Umożliwiło to śledzenie widm absorpcyjnych poszczególnych związków chemicznych.

Dla lepszego zobrazowania postępów badań nad chlorofilem prezentujemy poniżej kalendarium, jakie skompletował Paul Walden (1863-1957) w swojej znakomitej pracy „Geschichte der Organischen Chemie”.

1819 J. Pelletier i J. B. Caventou wprowadzają dla barwnika zielonych liści nazwę "chlorofil".

1837 J. J. Berzalius rozpoczyna pierwsze wyczerpujące badanie „zieleni liścia” lub „Chlorofili” i wyróżnia trzy ich modyfikacje $(\alpha, \beta, \Upsilon)$.

1851 F. Verdeil zwraca uwagę na podobieństwo pigmentów liści i krwi.

1860 E. Femmy przeprowadza ważne metodycznie badanie: w układzie roztwór wodny kwasu solnego - eter rozdziela żółtą filoksantynę, pozostającą w warstwie eterowej, od niebieskiej „filocyjaniny”, przechodzącej do warstwy wodnej; wodorotlenek glinu tworzy ciemnozielony lak, a żółte komponenty barwnika rozpuszczają się w alkoholu.

1870 K. Timirjaziew nazywa zielony komponent „chlorofiliną” (komponent uzyskany $\mathrm{z}$ alkoholowego wyciągu z liści, traktowanego alkaliami i kwasami) i przeprowadza spektralną analizę chlorofili.

1872 A. Bayer uważa, że otrzymał ciało podobne do chlorofilu na drodze syntezy $\mathrm{z}$ furfurolu i rezorcynolu.

1876 A. Mayer stwierdza, że w zielonych substancjach chlorofilowych regularnie występuje żelazo.

1879 F. Hoppe-Seyler równocześnie z A. Gautierem otrzymuje „krystaliczny” chlorofil (chlorofilan). Według analizy Hoppe-Seylera zawiera on 1,38\% fosforu i $0.34 \%$ magnezu; w dalszych swych pracach sprawy występowania magnezu Hoppe-Seyler nie podnosit.

1880 F. Hoppe-Seyler stwierdza, że niebiesko-purpurowy roztwór uzyskanej „filoporfiryny" swoimi własnościami spektroskopowymi przypomina „hematoporfirynę" krwi.

\footnotetext{
${ }^{3} \mathrm{~J}$. Rodzeń : Nie wszystko zaczęło się od Bunsena i Kirchoffa - nieznane wątki wczesnej historii spektroskopu optycznego, „Prace Komisji Historii Nauki PAU” t. 11: 2012, s. 227-270.

${ }^{4}$ P. Wal d e n: Geschichte der Organischen Chemie, Berlin 1941, t. 2, s. 715-717.
} 
$1881 \mathrm{~J}$. Borodin zauważa pod mikroskopem kryształki chlorofilu (rozpoznane przez M. Cwieta jako mieszanina).

1884 A. Tschirch publikuje Undersuchung über das Chlorophill.

1885 E. Schunck rozpoczyna badania nad filoksantyną i filocyjaniną i przekształceniem filoksantyny w filocyjaninę. Filocyjaninę (Femmy) rozpoznaje jako słabą zasadę, rozpuszczającą się w alkaliach i tworzącą z solami metali takich jak miedź, cynk, żelazo, srebro zielono zabarwione osady, nierozpuszczalne w wodzie, średnio rozpuszczalne w rozpuszczalnikach organicznych i nie ulegające rozkładowi z siarkowodorem. Według Schuncka metal odgrywa w nich taką rolę jak żelazo w hematynie; trzeba więc zaliczyć chlorofil do kompleksowych związków metali.

1893 N. Monteverde izoluje mikrokrystaliczny chlorofil, stosując metodę Krausa.

1894 E. Schunck i L. Marchlewski donoszą, że filocyjanina daje z octanem miedzi „sól podwójną" $\mathrm{C}_{68} \mathrm{H}_{71} \mathrm{~N}_{5} \mathrm{O}_{17} \mathrm{Cu}_{2}$.

1895 E. Schunck i L. Marchlewski uzyskują „filoporfirynę” $\mathrm{C}_{16} \mathrm{H}_{18} \mathrm{ON}_{2}$ i stwierdzają podobieństwo jej widma absorpcji z widmem hematoporfiryny Nenckiego. Na tej podstawie wnioskują o podobieństwie barwników liści i krwi. Obserwują też powstawanie z filoporfiryny związku pirolowego.

1896 A. Tschirch obserwuje w widmach UV pochodnych chlorofilu pasmo odpowiadające fioletowemu pasmu Soreta we krwi; to samo twierdzą Schunck i Marchlewski. 1896 M. Nencki podnosi sprawę genetycznego pokrewieństwa barwników liści i krwi; Nencki i J. Zaleski postulują, że filoporfiryna jest pochodną pirolową, podobną do hematoporfiryny.

1900 M. Cwiet wyróżnia w „krystalicznym chlorofilu” Borodina $\alpha-i \beta-$ chlorofiliny.

1903 C.A. Schunck stwierdza na drodze spektroskopowej, że żółtymi barwnikami kwiatów są trzy ksantofile (L,B,Y).

1906 M. Cwiet wprowadza „chromatograficzną analizę absorpcyjną” i oddziela żółte komponenty barwne (karotynoidy) od niebieskiej $\alpha$-chlorofiliny i zielonej - chlorofiliny.

1915 R. Willstätter otrzymuje nagrodę Nobla w dziedzinie chemii za badania nad barwnikami roślinnymi, w tym również nad chlorofilem.

1930H. Fischer z Wyższej Szkoły Technicznej w Monachium otrzymuje Nagrodę Nobla za badania nad konstytucją hemu i chlorofilu w szczególności nad syntezą hemu. https://pl.wikipedia.org/wiki/Uniwersytet_Techniczny_w_Monachium

Jak zatem widać zagadnieniami gruntownego przebadania chlorofilu, jego wyizolowania i zachowania pod wpływem czynników chemicznych zajmowało się 
wielu uczonych na przestrzeni wielu lat, natomiast wyjaśnienie natury chlorofilu nastręczało wiele trudności i przyniosło szereg niejasnych wyników. Naturę chlorofilu badano więc drogą pośrednią, poprzez jego pochodne.

Metodę, w której wyodrębnia się chlorofil z zielonych części roślin, została odkryta jeszcze w XVIII w. przez wspomnianego już wyżej Rouella. Na pierwszy rzut oka - i tak do pewnego czasu przypuszczano - wydaje się, że wyciąg z liści jest roztworem jednego barwnika zielonego. Dopiero z biegiem czasu badania dowiodły, że jest on mieszaniną kilku barwników żółtych i zielonych, które można rozdzielić na zasadzie różnej rozpuszczalności. Roztwór żółty poddany badaniom w spektroskopie wykazywał widmo absorpcyjne w czerwonej części widma, co naprowadziło uczonych do wniosku, że znajduje się w roztworze żółtym barwnik pokrewny chlorofilowi. Nazwano go allochlorofilem. ${ }^{5}$

„Na szczególną uwagę - jak pisał o tym później Leon Marchlewski - zasługuje działanie kwasów na chlorofil. Pod ich wpływem barwa roztworów alkoholowych szybko lub powoli, względnie do siły kwasu zmienia się na żółto-brunatną, a spektroskop natychmiast wykazuje, że chlorofil musiał w tych warunkach ulec jakiejś zmianie, gdyż widmo roztworu zawiera obecnie, cztery lub pięć prążków ułożonych nieco inaczej niż w widmie chlorofilu normalnego" ${ }^{6}$.

Zjawisko zyskało sobie miano „modyfikacji chlorofilu”, a jego przyczyny nie były początkowo znane. Dopiero w latach 1879-1880 niemiecki fizjolog i chemik Felix Hoppe-Seyler (1825-1895), znany ze swoich badań nad strukturą hemoglobiny, niemal równocześnie z francuskim lekarzem i chemikiem Armandem Gautierem (1837-1920), wydzielił z wyciągów alkoholowych materiału roślinnego ciało krystaliczne, które pod względem optycznym, jak dowiódł szwajcarski farmaceuta Alexander Tschirch (1856-1939), zachowywało właściwości chlorofilu. Związek ten nazwano chlorofilanem ${ }^{7}$.

Z biegiem czasu okazało się, że pochodna otrzymana przez Hoppe-Seylera nie ma struktury jednolitej, lecz jest w istocie mieszaniną co najmniej dwu związków różniących się od siebie stopniem zasadowości tj. filoksantyny, mającej właściwości słabej zasady, oraz filocyjaniny. W 1885 r. Schunck opublikował pierwsze wyniki swoich badań nad obiema substancjami. Prowadziły one w konsekwencji do prób przekształcenia filoksantyny w filocyjaninę ${ }^{8}$. Był to wynik wówczas już paroletnich pogłębionych studiów angielskiego badacza nad chemią chlorofilu, które rozpoczął jeszcze w 1879 r. Pierwszą rośliną, z której Schunck pozyskał badany barwnik był

\footnotetext{
${ }^{5}$ H. M a la r s ki : Z chemii chlorofilu, "Chemik Polski” R. 11: 1911 nr 1, s. 2.

${ }^{6}$ L. Mar ch lew s ki : Z chemii chlorofilu, „Wszechświat” t. 14: 1895 nr 19, s. 290

${ }^{7}$ S.W. J o h n s o n: How crops grow. A treatise on the chemical composition, structure and life of the plant, for students of agriculture, 0. Judd Company. New York 1890, s. 125.

${ }^{8}$ E. S chunck: Contributions to the Chemistry of Chlorophyll, „Proceedings of the Royal Society of London" t. 39: 1885, s. 348-361.
} 
eukaliptus gałkowy (Eucalyptus globulus ) gatunek z rodziny mirtowatych'. W 1888 r. Schunck wyizolował z materiału roślinnego krystaliczną formę barwnika, której nadał nazwę „phyllotaonina” ${ }^{\prime 10}$. W tym samym czasie podjął również prace z zakresu chemii paleoorganicznej. Przy użyciu metod spektroskopowych dokonał analizy chlorofilu obecnego w skamielinach pochodzących z wykopalisk w okolicach Manchesteru (Manchester Ship Canal) ${ }^{11}$. Warto wspomnieć o korespondencji, jaką Schunck prowadził wówczas ze Georgem Gabrielem Stokesem (1819-1903), fizykiem i profesorem matematyki w Cambridge, a której tematem była chemia chlorofilu. Schunck i Stokes prócz listów przesyłali sobie pocztą próbki uzyskanych w laboratoriach substancji. Tą właśnie drogą do rąk Stokesa trafiło czternaście próbek surowca marzanny wraz z prośbą o pomoc w wyizolowaniu nieuchwytnej purpuryny przy użyciu spektroskopii fluorescencyjnej. Prośba Schuncka była zrozumiała, zważywszy, że to właśnie Stokes wskazał na zjawisko fluorescencji, czyli emisji promieniowania przez naświetlaną substancję jako na obiecującą metodą analityczną ${ }^{12}$. W 1852 r. sformułował on prawo, mówiące, że długość fali promieniowania fluorescencyjnego jest zawsze większa od długości fali promieniowania wzbudzającego fluorescencję - nazwane prawem Stokesa, zaś różnica energii pomiędzy pikiem emisji a pikiem absorbcji to przesunięcie Stokesa.

Stokes potwierdził, że alizaryna i purpuryna nie dają identycznych widm fluorescencji. Co więcej, udało mu się odnaleźć purpurynę w ponad dwudziestu gatunkach roślin z rodziny Rubiaceae. Stokes również dokonywał prób izolacji chlorofilu uzyskując jednak wyniki różne od tych uzyskanych przez Schuncka. Jak się później okazało prace Schuncka poszły fałszywym tropem, co wpłynęło nań deprymująco i w końcu zniechęciło go do dalszych poszukiwań. Był nawet bliski całkowitego porzucenia badań. Jego ostateczna decyzja co do dalszej pracy była jednak inna. W 1892 r. zatrudnił kolejnego asystenta, którym był Leon Marchlewski. Jak się miało okazać otwierał się nowy etap badań nad chlorofilem, a pomiędzy 1894 r. a 1896 r. obu uczonym na tym polu badań udało się ustalić szereg wręcz fundamentalnych faktów ${ }^{13}$.

Jeszcze w latach 1880. wykazano, że alkoholowe roztwory chlorofilu pod wpływem działania na nie kwasami zachowują się w odmienny sposób. Stwierdzono, że w zależności od mocy kwasu otrzymywano roztwory posiadające widma absorpcyj-

${ }^{9}$ E. S ch unck: Note on modified Chlorophyll from the leaves of Eucalyptus globulus, „Proceedings of the Manchester Literary and Philosophical Society” t. 19: 1880, s. 157-160.

${ }^{10} \mathrm{E}$. S c h u n c k: Conributions to the chemistry of chlorophyl. No III, Proceedings of the Royal Society of London, t. 44: $1888 \mathrm{nr} 266-272$, s. 451. doi: 10.1098/rspl.1888.0062

${ }^{11} \mathrm{E}$. S ch u n ck: On the Green Colouring Matter from Leaves found in one of the Cuttings for the Manchester Ship Canal, „Memoirs of the Manchester Literary and Philosophical Society” 4: 1889 2, s. 231-233.

${ }^{12}$ W.V. F a r r a r: Edward Schunck, F.R.S. A Pioneer of Natural-Product Chemistry, „Notes and Records of the Royal Society of London" t. 31: 1977 nr 2, s. 280-281.

${ }^{13}$ Tamże, s. 289. 
ne z czterema lub pięcioma pasmami. Zjawisko to zostało dokładnie zbadane przez dwóch angielskich uczonych Williama Jamesa Russella (1830-1909) i Williama Lapraika (1800-ok.1856) ${ }^{14}$. Wykonali oni doświadczenia z użyciem kwasu octowego, winowego i kwasów mineralnych, lecz zjawisk tych przez długi czas nie potrafiono wytłumaczyć. Dopiero Marchlewski z Schunckiem wysnuli przypuszczenie, że zależy ono od stopniowego tworzenia się filoksantyny i filocyjaniny pod wpływem dodawanych kwasów i że kształtowanie się tych pochodnych jest zależne od charakterystyki użytych kwasów, temperatury oraz czasu ich oddziaływania. Tak zatem, działając stosunkowo słabym kwasem, jakim jest kwas octowy, na chlorofil uzyskamy w efekcie filoksantynę. Poddanie chlorofilu przedłużonemu działaniu kwasu winowego skutkuje powstaniem filocyjaniny. Z kolei przy użyciu mocnych kwasów mineralnych, jak np. kwas solny, etap tworzenia się filoksantyny nie jest widoczny i natychmiast powstaje filocyjanina ${ }^{15}$.

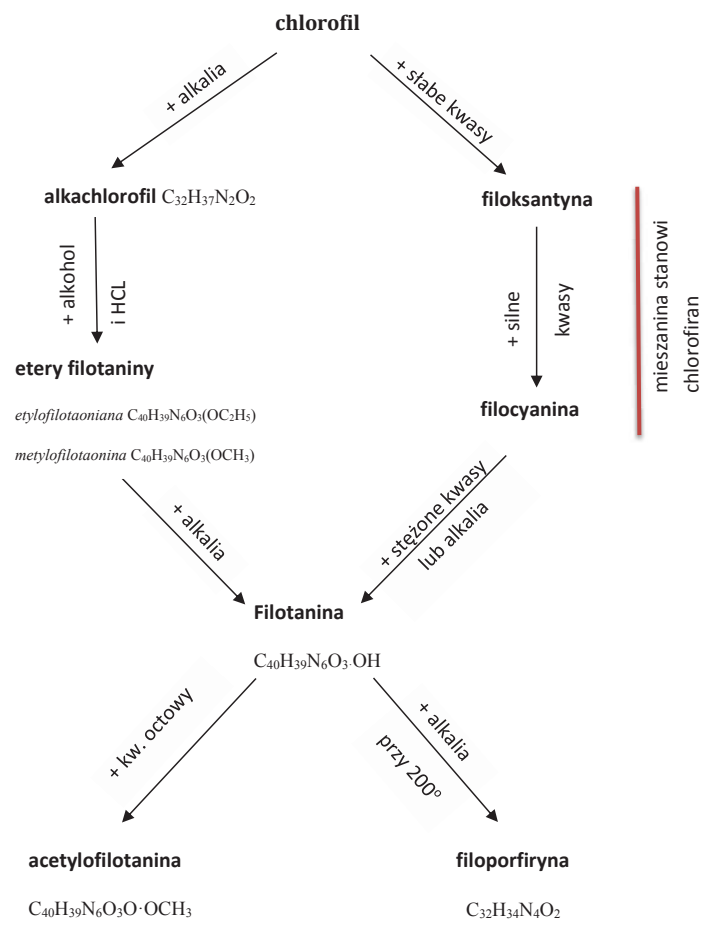

${ }^{14}$ W. J. R u s s ell, W. La prai k: A spectroscopic study of chlorophyll, „Journal of the Chemical Society, Transactions" t. 41: 1882, s. 334-341.

${ }^{15}$ Tej problematyce badacze poświęcili cykl prac: E. S ch u n ck: Contributions to the Chemistry of Chlorophyll; No. IV, „Proceedings of the Royal Society of London” t. 50: 1891, s. 143144, E. Schun ck, L. March l ews ki : Zur Chemie des Chlorophylls, „Justus Liebigs Annalen der Chemie” t. 278: 1894, s. 329-345, Ci s a m i: Zur Chemie des Chlorophylls, „Justus Liebigs Annalen der Chemie" (Zweite Abhaldung) t. 284: 1895, s. 81-107. 
Przebadano także skutki odziaływania zasad na roztwory alkoholowe chlorofilu, wykazując, że jakkolwiek zachowują one praktycznie niezmienione cechy fizyczne, to jednak analiza widm absorpcyjnych jasno dowodzi, że doszło do przemiany na poziomie chemicznym. Kwestia ta miała zaprzątać uwagę badaczy w kolejnych latach.

Na sąsiedniej stronie przedstawiamy schemat powstawania pochodnych chlorofilu pod wpływem czynników chemicznych, zaproponowany przez Marchlewskiego. Schemat ów pierwotnie został wydrukowany na łamach czasopisma „Wszechświat” i dobrze obrazuje stan wiedzy na temat chlorofilu w $1895 \mathrm{r}^{16}$

Należy w tym miejscu odnotować, że 1895 r. był przełomowym w historii badań nad chlorofilem, i jak się okazało, przełomowym w historii biochemii w ogóle. Wówczas bowiem Schunck i Marchlewski opublikowali wynik swoich badań porównawczych dotyczący widm absorpcyjnych wyodrębnionej przez nich z materiału roślinnego pochodnej chlorofilu o wzorze sumarycznym $\mathrm{C}_{32} \mathrm{H}_{34} \mathrm{~N}_{4} \mathrm{O}_{2}$, która wykazywała zaskakującą zbieżność z poznaną wcześniej filoporfiryną. Co jednak bardziej istotne dostrzegli oni, że w badaniach nad pochodnymi hemoglobiny, które prowadzili w Petersburgu Marceli Nencki i Nadina Sieber (1854-1916), uzyskano związek o wzorze sumarycznym $\mathrm{C}_{32} \mathrm{H}_{34} \mathrm{~N}_{4} \mathrm{O}_{5}$ - bezwodnik kwasowy hematoporfiryny. Różnica zatem wynosiła zaledwie trzy atomy tlenu. Podążając dalej tym tropem wykazali zbieżność cech fizycznych, takich jak barwa i gęstość obu roztworów. Zaobserwowali natomiast różnice m.in. w przebiegu ich krystalizacji. By ostatecznie zweryfikować swoje przypuszczenia zdecydowali się porównać widma absorpcyjne „filoporfiryny” (taką właśnie nazwę uczeni przyjęli) oraz hematoporfiryny. Wyniki przeszły ich oczekiwania. Pisali wówczas: „The absorption spectra of the two substances exhibit a remarkable resemblance; one may almost say they are identical ${ }^{\prime 17}$.

Na tej podstawie Schunck i Marchlewski stawiali tezę o istotnym chemicznym pokrewieństwie pochodnych barwników liści i krwi, a co za tym idzie pokrewieństwie chlorofilu i hemoglobiny. Warto przypomnieć, że Schunck oddał Marchlewskiemu pierwszeństwo w tym odkryciu, co tyleź świadczy o talencie polskiego badacza, co wysokiej próbie charakteru Anglika. Pisał :,,The discovery was made in my laboratory but the merit of it is chiefly due to my friend and former collaborator $d r$ Marchlewski" ${ }^{18}$.

Wyniki uzyskane wówczas przez Schunka i Marchlewskiego znalazły pełne uznanie w oczach Nenckiego, który otrzymawszy od polskiego kolegi próbkę

\footnotetext{
${ }^{16}$ L. March lews ki : Z Chemii Chlorofilu (dokończenie), „Wszechświat” t. 14: 1895, nr 20, s. 310.

${ }^{17}$ E. S ch u n ck, L. March lew ski: Contributions to the Chemistry of Chlorophyll; No. VII. Phylloporphyrin and Haematoporfyrin: Comparision, „Proceedings of the Royal Society of London" t. 94: 1895, s. 234.

${ }^{18}$ Cytat za: I.Z. Si e mi o n: Notatki Chaotyczne, „Wiadomości Chemiczne” t. 57: $2004 \mathrm{nr}$ 7-8, s. 677-678.
} 
filoporfiryny i zapoznawszy się z metodyką badawczą obu badaczy już w $1896 \mathrm{r}$. wysoko ocenił ich pracę ${ }^{19}$.

Badania nad właściwościami chlorofilu, które Marchlewski prowadził w Anglii, dobrze znane były nad Wisłą. W 1900 r. Uniwersytet Jagielloński organizował Zjazd Przyrodników i Lekarzy. W liście z 4 stycznia tegoż roku sekretarz sekcji chemicznej dr Tadeusz Estreicher zwrócił się do Marchlewskiego z prośbą o wygłoszenie referatu. Pisał m.in.:

Sekcja Chemiczna, pragnąc zapewnić sobie szereg wykładów, któreby - prócz efemerycznej wartości referatów - będąc owocem samodzielnych badań i ogarniając szerszy zakres w poszczególnych gałęziach chemii, nadawały w pierwszym rzędzie wartość i interes posiedzeniom Sekcji, postanowiła zwrócić się z prośbą o odpowiednie wykłady do wybitnych przedstawicieli naszej nauki w kraju i poza nim. Z tego powodu Komitet Sekcyjny ma zaszczyt zwrócić się do Szanownego Pana z uprzejmą prośbą, by Szan. Pan zechciał łaskawie, w razie przybycia - jak mamy nadzieję - do Krakowa na czas Zjazdu, wypowiedzieć odczyt z zakresu chemii chlorofilu ${ }^{20}$.

\section{Stan badań nad indygo na przełomie XIX i XX stulecia}

Warto w tym miejscu nieco bliżej przypomnieć historię badań nad indygo, w których kluczową rolę odegrał Schunck, a swój udział miał również Marchlewski. Indygo było używane w sztuce farbiarskiej od najdawniejszych czasów. Pierwsze znane nam przekształcenie aniliny w indygo miało miejsce w latach 1820 , a na przełomie lat 1830. i 1840. Carl Julius Fritzsche (1808-1871), pracując nad syntezą indyga, uzyskał kwas antranilowy ${ }^{21}$. Z kolei 1841 r. Auguste Laurent (1807-1853) i Otto Erdmann (1804-1869) dokonali utlenienia indygo kwasem azotowym, uzyskując z indyga izatynę. Sporo uwagi indygo oraz izatynie poświęcił Adolf von Baeyer (18351917), który w cyklu prac powstałych w latach 1866-1882 zgłosił propozycje wzorów strukturalnych dla indyga, izatyny oraz indoksylu ${ }^{22}$. Ostatecznie w $1883 \mathrm{r}$. Bayer przedstawił wzór indygo ${ }^{23}$.

${ }^{19}$ R. W. Gryg le w s ki : Biochemiczna rewolucja, czyli rzecz o Leonie Marchlewskim i Marcelim Nenckim, „Wiadomości Chemiczne” t. 69: 2015 nr 5-6, s. 474.

${ }^{20}$ Fragment listu dr Tadeusza Estreichera do Leona Marchlewskiego. Zbiory specjalne KHM UJ CM/Teczka prof. L. Marchlewskiego

${ }^{21}$ F. E. S h e i b l ey: Carl Julius Fritzsche and the discovery of anthranilic acid, 1841, „Journal of Chemical Education" t. 20: 1943 nr 3, s. 115-117 DOI: 10.1021/ed020p115

${ }^{22}$ W. K r o s z c zy ń s k i : Krótka historia niektórych wzorów, „Wiadomości Chemiczne” t. 67: 2013, nr 7-8, s. 733-749.

${ }^{23}$ A. B a e yer: Ueber die Verbindungen der Indigogruppe, „Berichte der Deutschen chemischen Gesellschaft zu Berlin" t. 16: 1883, s. 2188-2204. 
Tymczasem Schunck, współpracując z wiodącym wówczas egiptologiem Flindersem Petrie (1853-1942), przebadał próbki tkanin pobranych z mumii odkrytych podczas wykopalisk w Lahun pod koniec lat 1880. Pomiędzy różnymi barwnikami Schunck zidentyfikował wówczas również indygo, jako najbardziej prawdopodobną podstawę wytwarzania barwnika niebieskiego ${ }^{24}$. Schunckowi też zawdzięczamy prace badawcze nad roślinami indygodajnymi. Badacz ten udowodnił, że wbrew dawniejszym przypuszczeniom rośliny nie zawierają indygotyny pod żadną postacią, a barwnik ten powstaje dopiero przy rozkładzie pewnej substancji macierzystej, nazwanej przez Schuncka indykanem ${ }^{25}$. To odkrycie zawdzięczał wieloletnim doświadczeniom z kraplakiem oraz podjętym jeszcze w 1850 r. pracom nad naturalnym barwnikiem indygo pozyskanym z rośliny urzet barwierski (Isatis tinctoria) gatunkiem z rodziny kapustowatych, którą to roślinę uczony uprawiał we własnym przydomowym ogrodzie. Były to badania czysto naukowe i niewiążące się z pracą dla potrzeb przemysłu. Niewątpliwie przełomem dla tego kierunku poszukiwań był fakt zatrudnienia w 1875 r. przez Schuncka asystenta Hermana Römera z Uniwersytetu w Berlinie, który stał się właściwie częścią rodziny. To najprawdopodobniej pod jego wpływem Schunck odnowił zainteresowanie kraplakiem, w szczególności zaś zawartą w tym barwniku alizaryną. Trwająca zaledwie cztery lata współpraca była intensywna i zaowocowała wydaniem dziewiętnastu publikacji dotyczących barwników antrachinonowych. Na znacznie szybsze tempo pracy w porównaniu do poprzednich samodzielnych eksperymentów wykonywanych przez Schuncka wpłynął fakt wykorzystywania przez Römera temperatury topnienia podczas doświadczeń. Zaoszczędziło to badaczom wielu godzin żmudnej pracy.

W 1879 r. Schunck dzięki współpracy z Hermannem Römerem stwierdził, że indygotyna tworzy się z indykanu poprzez odziaływanie na nią kwasu solnego w obecności środka utleniającego. Innymi słowy konieczne jest równoczesne występowanie dwóch czynników: hydrolizującego i utleniającego ${ }^{26}$. Nadal jednak sprawa nie była do końca wyjaśniona i dlatego dyskutowana. W 1898 r. Marchlewski, współpra-

${ }^{24}$ E. S ch unck: Notes on some ancient dyes. "Memoirs and Proceedings of the Manchester Literary and Philosophical Society" t. 5: 1892 Seria 4, s. 158-161; L. M a r ch le w s ki: Indygo „Wszechświat" t. 17: 1898 nr 37, s. 581.

${ }^{25}$ Problemowi chemicznej struktury indygo Schunck poświęcił szereg prac publikując na ten temat już w latach 1850. Patrz m. in.; E. S ch un c k: On the Formation of Indigo-blue. Part 1, „Memoirs of the Manchester Literary and Philosophical Society” t. 12: 1855 Seria 2, s. 177-208, tenże: On the Formation of Indigo-blue. Part 2, „Memoirs of the Manchester Literary and Philosophical Society" t. 14: 1856 Seria 2, s. 181-237; te n ż e: On the Occurrence of Indigo-blue in Urine, „Memoirs of the Manchester Literary and Philosophical Society” t. 14: 1857 Seria2, s. 239-249.

${ }^{26}$ E. S c h u n ck, H. Rö m e r : Ueber die Zersetzung des Pflanzenindicans bei Abschlus der Luft, „Berichte der Deutschen chemischen Gesellschaft” t. 12: 1879, s. 2311-2312; E. S ch u n ck: On Indigo-blue from Polygonum tinctorium and other Plants, „Chemical News” t. 39: 1879, s. 119-120, s. 129-130, s. 143-144. 
cując wówczas z L. G. Redcliffem, zgłosili nową propozycję budowy indykanu ${ }^{27}$. Tak pisał o tym sam Marchlewski:

Sądzę, że z zachowaniem się indykanu zgadza się najlepiej następujący pogląd na chemiczną jego naturę: indykan jest glukozydem indoksylu, to jest związku, otrzymanego drogą sztuczną między innymi z pewnego produktu utlenienia indygotyny, izatyny, a mającym w nowszych syntezach indygotyny pierwszorzędne znaczenie. Według poglądu tego proces tworzenia się indygotyny z indykanu tłumaczy się w sposób następujący: środki hydrolizujące rozkładają indykan na glukozę i indoksyl, który pod wpływem tlenu powietrza lub innych środków utleniających przemienia się natychmiast w indygotynę; jeżeli zaś środki utleniające są nieobecne natenczas indoksyl, utworzony podczas hydrolizy, będąc związkiem łatwo wchodzącym w reakcje z aldehydami lub związkami łatwo w nie zamienianymi, łączy się prawdopodobnie z glukozą, tworząc związek izomeryczny z indykanem, lecz bardzo trwały, niezdolny do przemiany w indygotynę przy późniejszym działaniu środków utleniających ${ }^{28}$.

Z tego wynikało, iż indykan nie zawiera w sobie całej cząsteczki indygotyny. Podczas hydrolizy indykanu zachodzi równocześnie proces kondensacji, skutkiem czego powstaje indygotyna. Związkiem macierzystym indygotyny jest zatem indoksyl, a więc hipotetyczny wzór indykanu na podstawie ustaleń Marchlewskiego przedstawiał by się następująco:

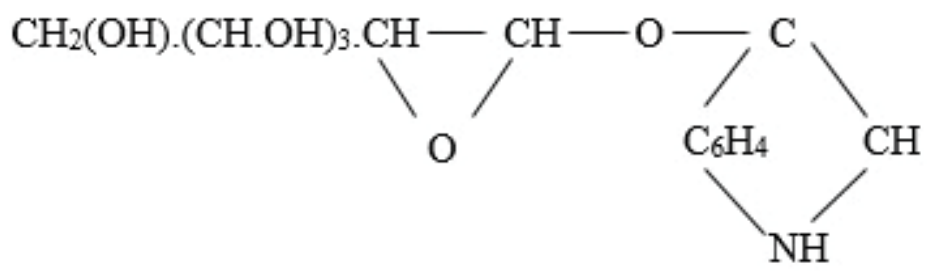

Skondensowana tu jest jedna cząsteczka indoksylu z jedna cząsteczką glukozy z wydzieleniem jednej cząsteczki wody, która tworzy się z jednego atomu wodoru z glukozy i jednej grupy hydroksylowej z indoksylu lub odwrotnie.

Jak podkreślał Jan Bielecki (1869-1926), powyższy hipotetyczny wzór indykanu pozwalał na wyjaśnienie zarówno procesu jego powstawania w obecności kwasów przy braku środków utleniających, jak i pokazywał mechanizm tworzenia się glukozy i indygotyny pod wpływem kwasów przy równoczesnym utlenianiu ${ }^{29}$. Była to za-

${ }^{27} \mathrm{~L} . \mathrm{M}$ a r c hl e w s k i , L. G. R a d cliff e : Note on the constitution of indican and some derivatives of indigotin. "Journal of the Society of Chemical Industry" t. 17: $1898 \mathrm{nr} 5$, s. 430-436, ci sami: Zur Kentniss des Indigotins. „Journal für practische Chemie” t. 58: 1898 nr 1, s. 102-109.

${ }^{28}$ L. M a r chle w s ki : Indygo, „Wszechświat” t. 17: 1898 nr 37, s. 583.

${ }^{29} \mathrm{~J}$. Bi e le cki : Chemia indyga i rozwój metod technicznych otrzymywania indyga naturalnego i sztucznego, „Chemik Polski” t. 1: $1901 \mathrm{nr}$ 1, s. 19-20. Prezentowany schemat powstał w oparciu o rysunek pochodzący z tejże pracy. 
tem znacząca różnica wobec wcześniejszych propozycji zgłaszanych przez Schuncka i Römera. Nowa propozycja rozwiązania problemu budowy indykanu była też według Bieleckiego bardziej prawdopodobna również z punktu widzenia funkcji fizjologicznych organizmów żywych. Dodatkowym argumentem, jaki Bielecki znajdował za przyjęciem rozwiązania zgłaszanego przez Marchlewskiego, było podobieństwo do wzoru kwasu indygosulfonowego (estru sulfonowego indoksylu), który odnajdowano w wydzielinach organizmów zwierzęcych. Skłaniało to Bieleckiego do przyjęcia założenia, że w niektórych gatunkach roślin „produktem rozkładu białka bywa również indoksyl”, którego obecność jest tym bardziej prawdopodobna, że zarówno rośliny, jak i zwierzęta, wytwarzają często z białka związki chemiczne względem siebie pokrewne, np. filoporfirynę i hematoporfirynę $e^{30}$.

Potwierdzenia teorii Marchlewskiego dostarczały prace Sebastiana Hoogewerffa (1847-1934) oraz Henri Ter Meulena (1871-1942) nad indykanem ${ }^{31}$. Wydzielili oni z liści Polygonum tinctorium (rdestu barwierskiego - pochodzącego z Chin i Japonii) lub Indigofera leptostachya, czysty indykan pod postacią kryształków ortorombicznych. Indykan krystaliczny odpowiadał wg badaczy wzorowi $\mathrm{C}_{14} \mathrm{H}_{17} \mathrm{NO}_{6}$ a więc zgadzał się z wzorem zaproponowanym przez Marchlewskiego. Podobnie dyrektor stacji doświadczalnej do badania indyga w Klaten na Jawie J. J. Hazewinkel, stosując inną metodę doszedł do zbieżnych z polskim uczonym wniosków ${ }^{32}$.

\section{Edward Schunck}

O Leonie Marchlewskim, profesorze chemii lekarskiej UJ, twórcy krakowskiej szkoły biochemicznej, z której wywodzić się będzie m.in. Bolesław Skarżyński napisano już wiele. Nie sądzimy zatem by zasadnym było prezentować jego biografię i omawiać szczegółowo jego dorobek, odsyłając zainteresowanych do gotowych już opracowań ${ }^{33}$. Natomiast warto jest przybliżyć postać autora litów - Edwarda Schuncka, o którym w polskiej literaturze przedmiotu jest znacznie mniej informacji.

Henry Edward Schunck urodził się 16 sierpnia 1820 r. w Manchesterze w rodzinie luterańskiej, jako najmłodszy syn Martina Schuncka i Susanny Mylius - córki frankfurckiego senatora Johanna Jacoba Myliusa ${ }^{34}$. Rodzina Schuncków, o której

\footnotetext{
${ }^{30} \mathrm{~J}$. Bielecki:s. 20.

${ }^{31} \mathrm{~S}$. H o og e werff, H. Ter Meule n: Contribution to the knowledge of Indican, „Royal Netherlands Academy of Arts and Sciences (KNAW) Proceedings" t. 2: 1899-1900, s. 520-525.

${ }^{32} \mathrm{~J}$. J. H a z e w in k e l: Indigo - its hydrolysis and the enzyme causing the same, „Royal Netherlands Academy of Arts and Sciences (KNAW) Proceedings" t. 2: 1899-1900, s. 512-520.

${ }^{33}$ W. Ostrowski: Leon Marchlewski (1869-1946), „Folia Biologica” t. 14: $1966 \mathrm{nr} 4$, s. 341-345; M. S a r n e cka-Kell er, J. H u le w i c z: Marchlewski Leon Pawet, PSB t. 17: 1974, s. 542-545; B. Skarżyński, Leon Marchlewski (1869-1946), [w:] Sześćsetlecie medycyny krakowskiej pod red. L. To c h o w i c z a, Kraków 1963, t. 1, s. 313-333.

${ }^{34}$ T. E. James, T. Travis: Oxford Dictionary of National Biography. [za:] http://www. oxforddnb.com/index/101035974/Edward-Schunck (dostęp: 27.05.2017)
} 
najdalsze wiadomości sięgają 1600 r., miała korzenie niemieckie. Dziadek Edwarda Johann Carl Schunck (1745-1800) był poborcą podatkowym. Jego córka Helene poślubiła Charlesa Souchaya (1768-1835). Souchay związany był z fachem kupieckim. Jego umiejętności handlowe, zdolność planowania i spryt umożliwiający osiągnięcie zysków zaowocowały utworzeniem dobrze prosperującej rodzinnej firmy kupieckiej. Firma przetrwała lata pierwszej wojny światowej oraz światowy kryzys gospodarczy w 1929 r. Z firmą związali się również trzej synowie Johanna Carla Schuncka- Philipp, Heinrich oraz Martin. W ten sposób jedno pokolenie rodziny Schuncków stworzyło rodzinny kupiecki klan ze znaczącą i stabilną pozycją na europejskim i międzykontynentalnym rynku tekstylnym. Martin Schunck (1788-1872) w młodości przebywał w Szwajcarii. Następnie po latach spędzonych na prowadzeniu intratnych kontaktów handlowych z Maltą osiedlił się w Manchesterze. Tam w 1815 r. powołał do istnienia firmę Schunck, Mylius zajmującą się spedycją towarów. W 1832 r. została ona przemianowana na Schunck, Souchay \& Co. Firma właściwie zmonopolizowała eksport towarów w Lancashire i Yorkshire.

Henry Edward Schunck od najmłodszych lat wykazywał duże zainteresowanie nauką. W tym czasie w Manchesterze nie było jeszcze uniwersytetu. Życie naukowe skupiało się wokół Stowarzyszenia Literacko-Filozoficznego (Literary and Philosophical Society) utworzonego w 1781 r. Schunck nie był jego formalnym członkiem, pozostawał natomiast w kręgu osób zaprzyjaźnionych. Tymi zaś, którzy wprowadzili Edwarda Schuncka w tajniki interesującego go świata chemii, byli William Henry oraz jego syn Charles Henry. Schunck wspominał ten moment następująco:

Mam powody, aby pamiętać doktora Charlesa Henry’ego. Kiedy usłyszał, że uczę się chemii tylko i wyłącznie z książek, zaoferował mi w sposób bardzo uprzejmy udzielenie praktycznych lekcji w tej dziedzinie wiedzy. Pokazał mi swoje laboratorium. Ciemne i obskurne pomieszczenie wydało mi się rajem, nieopisaną wspaniałością, której nigdy wcześniej nie widziałem. To on nauczył mnie podstaw analizy chemicznej ${ }^{35}$.

Dzięki rekomendacji Charlesa Henrego w 1840 r. Schunck wyjechał do Niemiec w celu podjęcia nauki na Uniwersytecie w Berlinie i Giessen. Giessen było wówczas wiodącym ośrodkiem nowoczesnej myśli chemicznej poszukującej dość kontrowersyjnych na owe czasy powiązań klasycznej chemii z fizjologią. Tymczasem firma Schunck and Mylius uruchomiła w angielskim Belfield fabrykę tekstyliów. Była to ważna inwestycja rodzinna i Martin Schunck z niecierpliwością oczekiwał powrotu syna, zamierzając powierzyć mu kierownictwo w dziale chemicznym fabryki. Edward powrócił do Anglii z tytułem doktora w 1842 r. i zgodnie z wolą ojca przez dwa lata wypełniał obowiązki na powierzonym mu stanowisku kierowniczym. Jednocześnie podjął prace nad barwnikami pochodzenia naturalnego otrzymanymi z aloesu oraz porostów. Z biegiem czasu Schunck coraz bardziej oddalał

${ }^{35}$ W.V. Farrar: s. 275. 
się od powszednich spraw fabryki, kierując swoją uwagę w stronę zagadnień czysto naukowych. Co ciekawe, nigdy nie był zainteresowany awansem akademickim. Swoim badaniom poświęcał nieograniczoną ilość czasu, nie chcąc, aby przynaglała go konieczność publikacji wyników. Był jednak zupełnie świadomy, że samodzielna praca naukowa mogła opóźniać go w zdobywaniu najnowszych wiadomości i doniesień w swojej dziedzinie. Zauważał też, że brak kontaktu ze studentami powodował u niego skłonność do pewnej opieszałości w pracy. Odczuwał wyraźnie brak stymulacji, jaką daje praca z młodymi adeptami nauki i wynikająca z tego konieczność uważnego czuwania nad stanem ich wiedzy. Badania nad barwnikami pochodzącymi z porostów Schunck zakończył dopiero po 3 latach, a więc w 1845 r.

Kolejnym (pod względem chronologicznym) zagadnieniem podjętym przez Schuncka były wspomniane już wcześniej badania nad kraplakiem, znanym od czasów starożytności barwnikiem otrzymywanym z korzenia marzanny barwierskiej ${ }^{36}$ (Rubia tinctorum L.) gatunku z rodziny Rubiaceae zawierającym związki barwiące alizarynę i purpurynę (związki antrachinonowe) ${ }^{37}$.

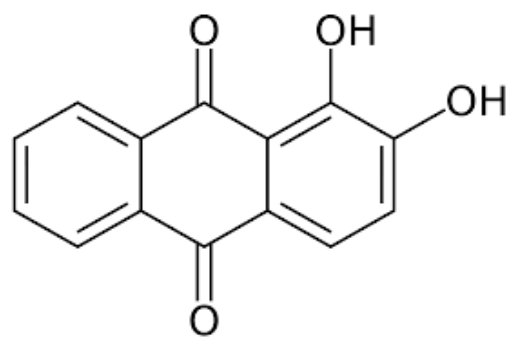

Alizaryna (dihydroksyantrachinon)

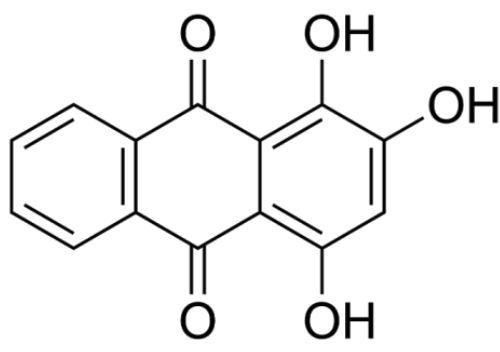

Purpuryna (trihydroksyantrachinon)

Schunck wyizolował z korzenia marzanny zarówno alizarynę, jak i szereg innych związków, którym nadał nazwy według własnej inwencji (m.in. „rubiadyna” i „rubiacyna” ${ }^{38}$. Mimo wielu nieścisłości odkrytych przez współczesnych badaczy mających do dyspozycji czułe metody analityczne należy podkreślić fakt, iż Schunck, dochodząc do swoich wyników, miał do dyspozycji jedynie takie kryteria podziału jak: kolor otrzymanej substancji, wygląd formy krystalicznej i rozpuszczalność, zaś narzędziem pracy były elementarne reakcje analityczne. Pierwszych izolacji i identyfikacji dokonał bez znajomości pojęcia temperatury topnienia. Ważne jest również podkreślenie faktu, że trudności w odizolowaniu purpuryny od alizaryny (związki te, jak wiadomo, różnią się tylko jedną dodatkową grupą hydroksylową w pierścieniu antrachinonu) doprowadziły Schuncka do podjęcia pierwszych prób wykorzy-

\footnotetext{
${ }^{36}$ Tamże, s. 277.

${ }^{37}$ B. B r o d a : Zarys botaniki farmaceutycznej, wyd. VI poprawione, PZWL. Warszawa 2002, s. 283.

${ }^{38}$ E. S c h un c k: On Rubian and Its Products of Decomposition, „Philosophical Transactions of the Royal Society", t. 143: 1853, s. 67-107. DOI: 10.1098/rstl.1853.0003.
} 
stania spektroskopii jako metody analitycznej w chemii organicznej, w czym, jak wspominaliśmy wyżej, miał swój udział Stokes.

W latach 1850. Schunck zainteresował się bliżej problemem, któremu poświęcił kilka lat wytężonej pracy, mianowicie poszukiwaniu obecności barwników w moczu. Schunck starał się udowodnić, że za niebieskie zabarwienie moczu odpowiada obecne w nim indygo. Mimo uzyskania śladowych ilości tego związku z moczu ostateczne wyniki nie dały zadowalających i znaczących z fizjologicznego punktu widzenia rezultatów ${ }^{39}$.

W latach 1860. Schunckowi powodziło się coraz lepiej, także pod względem finansowym. W 1864 r. przeprowadził się wraz z żoną Judith Howard Brooke (18301918) (poślubioną w r. 1851) do nowo wybudowanej rezydencji „Oaklands” w północno-zachodniej części Manchesteru. W miejscu tym osiadł na stałe i przebywał w nim całą pozostałą część życia. Przez jakiś czas kontynuował jeszcze prowadzenie spraw handlowych, lecz ich zakres stawał się coraz mniejszy, a głównym obszarem zainteresowań stały się zagadnienia czysto naukowe. Kontynuował swoje badania nad strukturą chemiczną moczu, w tym zawartym w nim barwnikami, a także nad indygo ${ }^{40}$. Po śmierci ojca w 1872 r. Schunck odziedziczył duży majątek, który przeznaczył na organizację na terenie rezydencji własnego pokaźnego i dobrze wyposażonego laboratorium oraz biblioteki. Jednocześnie jednak wyraźnie spadało tempo pracy. Wzrosło ono ponownie wraz z nawiązaniem współpracy z Römerem, o której była już wyżej mowa. Gdy w 1879 r. Römer powrócił do Berlina, Schunck pogrążył się ponownie w swej opieszałości, a także w odczuciu osamotnienia na polu naukowym, które ze względu na podeszły wiek stawało się dla niego jeszcze bardziej dojmujące. Warto podkreślić, że była to ocena czysto subiektywna. 0 poważaniu i powszechnym szacunku, jakim darzono Schuncka, świadczy m.in. jego członkostwo w Society for Chemical Industry w 1881 r., a także fakt powierzenia mu przewodniczenia sekcji chemicznej British Association w 1887 r.

Po wielu latach pracy nad zagadnieniami z dziedziny chemii był zainteresowany przyszłością tej gałęzi wiedzy. Starał się przewidzieć kierunek, w którym podąży chemia. Powiedział wówczas:

Myślę, że możliwe jest, że w niedalekim czasie, prawie wszystkie substancje, nad którymi obecnie pracujemy staną się możliwe do otrzymania, większość najważniej-

${ }^{39} \mathrm{E}$. S ch u n ck: XXXIV. On the occurrence of indigo-blue in urine, „The London, Edinburgh, and Dublin Philosophical Magazine and Journal of Science", t. 14: 185793 288-296. DOI: $10.1080 / 14786445708642392$

${ }^{40}$ Schunck opublikował wówczas szereg doniesień stanowiących raporty z bieżących postępów jego prac. Były to $\mathrm{m}$. in. E. S chunck: On some products derived from indigo blue, "Journal of the Chemical Society" 4: 1866 462-476, te nż e: On a crystalline fatty acid from human urine, „Proceedings of the Royal Society of London” 16: 1868 140-143, te n ż e: On the colouring and extractive matters of urine, „Proceedings of the Royal Society of London” 16: 1868 73-125. 
szych faktów zostanie już odkrytych i wtedy klasyczna chemia się wyczerpie, tak jak wyczerpała się już systematyka w naukach biologicznych. Nowe związki będą od czasu do czasu odkrywane tak jak obecnie odkrywamy nowe minerały i rośliny, lecz nic więcej nie rzuci nowego światła na teorie, które już znamy ${ }^{41}$.

Nowego bodźca do pracy i życia dodało Schunckowi spotkanie Marchlewskiego, który miał przebywać w Karsal przez 5 lat. Później, o czym będzie mowa poniżej, utrzymywali ze sobą stały kontakt listowy. Henry Edward Schunck zmarł 13 stycznia 1903 r. Według jego woli laboratorium oraz biblioteka zostały przekazane Uniwersytetowi w Manchesterze. Schunck żywił nadzieję, że praca jego życia będzie kontynuowana przez syna Charlesa. Ten jednak podjąwszy się tego zadania, w krótkim czasie je porzucił. Niezwykle cennym źródłem wiedzy o życiu i pracy naukowej Schuncka były jego pamiętniki. Niestety mimo licznych prób poszukiwań nigdy nie udało się ich odnaleźćc ${ }^{42}$.

\section{Leon Marchlewski i Edward Schunck w świetle korespondencji}

Jak już wyżej wspomniano do spotkania Marchlewskiego z Schunckiem doszło w 1892 r., kiedy rozpoczynający dopiero swoją karierę badawczą Polak przyjął zaproszenie od ponad siedemdziesięcioletniego uczonego dysponującego już znaczącym dorobkiem i pozycją w świecie nauki. Marchlewski dwa lata wcześniej ukończył politechnikę w Zurychu z tytułem „chemika technicznego” i został prywatnym, nieetatowym asystentem znakomitego profesora technologii chemicznej Jerzego Lungego (1839-1923) ${ }^{43}$. Lunge w owym czasie był jednym z najwybitniejszych specjalistów z zakresu problematyki ciężkiego przemysłu nieorganicznego, doradcą naukowym wielu potężnych firm przemysłowych, a równocześnie świetnym analitykiem. Pobyt w pracowni Lungego był dla Marchlewskiego znakomitą szkołą ścisłej metody naukowej, której piętno cechowało zawsze jego twórczość.

Niezależnie od współpracy z Lungem prowadził Marchlewski w jego laboratorium samodzielne badania, zarówno z zakresu chemii analitycznej, jak i z dziedziny chemii nieorganicznej strukturalnej i chemii fizycznej. W 1892 r. uzyskał na uniwersytecie w Zurychu tytuł doktora filozofii, przedkładając jako dysertację doktorską pracę pt. „Kritische Studien über die Sulfidschwefelbestimmungsmethoden”. Jak się miało jednak okazać ten obiecujący analityk-nieorganik nigdy już po opuszczeniu Zurychu do chemii nieorganicznej nie powrócił. ${ }^{44}$

Schunck, pragnąc dokończyć szereg projektów badawczych, poszukiwał jeszcze jednego asystenta. Znalazł go w osobie Marchlewskiego, który ofertę Schuncka przy-

\footnotetext{
${ }^{41}$ W.V. Farrar: s. 287.

${ }^{42}$ Tamże.

${ }^{43}$ M. Sarnecka-Keller, J. H u lewicz: s. 542.

${ }^{44}$ B. S karżyńs ki : s. 318
} 
jął i późną jesienią 1892 r. opuścił Zurych, przenosząc się do Kersal. Marchlewski, obejmując u niego stanowisko, wkroczył w zupełnie nową dla siebie dziedzinę chemii organicznej i chemii fizjologicznej roślin, ale szybko opanował ją po mistrzowsku, tak że po kilku latach stał się jednym z czołowych europejskich chemików-organików. W pierwszym rzędzie zajął się wówczas glikozydami, wkraczając w obszar badań związanych z barwnikiem indygo. W serii badań ustalił budowę chemiczną rubiadyny, proponując odpowiedni dla niej wzór chemiczny ${ }^{45}$. Jednocześnie rozpoczął prace nad chlorofilem i jego pochodnymi, których kulminacja nastąpiła, jak wyżej już odnotowano, w latach 1894-1895.

W 1897 r. w związku z tym, że Schunck ze względu na stan zdrowia ograniczał badania, Marchlewski przeniósł się do Clayton koło Manchesteru, aby tam objąć stanowisko kierownika pracowni naukowej fabryki barwników i produktów farmaceutycznych. Mimo to stosunki Marchlewskiego z Schunckiem pozostały w dalszym ciągu jak najserdeczniejsze; znakomity chemik angielski i młody polski badacz stanowili nie tylko parę harmonijnych współpracowników, ale również parę oddanych sobie kolegów. Marchlewski wielokrotnie podkreślał, że wiele zawdzięczał Schunckowi, nie tylko jako uczonemu, ale też jako człowiekowi ${ }^{46}$. Zachowany fragment korespondencji będący przedmiotem naszego zainteresowania dotyczy tych czasów, gdy bezpośrednia współpraca Marchlewskiego i Schuncka już ustała.

Na podstawie analizy posiadanej przez nas korespondencji można stwierdzić, że uczeni wymieniali ze sobą poglądy co do postępu prac badawczych w zakresie pochodnych chlorofilu, jak dotyczyło to np. wytwarzania alkachlorofilu, badań nad pozyskiwaniem etylofilotaoniny, zachowania się chlorofilu po przejściu przez przewód pokarmowy zwierząt. Schunck pisał również o swoich badaniach nad indygo, natomiast nie odnosił się do badań Nenckiego nad hemoglobiną i współpracy nad biochemią barwników w tym zakresie z Marchlewskim. Dzielił się z Marchlewskim kłopotami z uzyskiwaniem i oczyszczaniem pochodnych chlorofilu. Wielokrotnie poruszał $\mathrm{w}$ swoich listach problem $\mathrm{z}$ uzyskiwaniem etylowego eteru filotaoniny (etylofilotaoniny). Jak można wnosić, był to dla niego problem, z którym borykał się przez dłuższy czas, nie odnosząc na tym polu sukcesu. Na to zdają się wskazywać uwagi z dwóch listów pisanych latem 1899 r. W liście datowanym na dzień 4 czerwca 1899 r. Schunck pisał:

After discovering ettylphyllotaonin I was inclined to think it was simply that compound, but in opposition to that view might be set the fact that is in soluble in water.

May it not possible be an alkaline compound of an acid ettylphyllotaonin?

Oraz w późniejszym, z dnia 26 lipca tego samego roku, w którym odnosił się do pytania Marchlewskiego:

${ }^{45} \mathrm{~L}$. Marchlews ki: The constitution of rubiadinglucoside and rubiadin, „Journal of the Chemical Society Transactions" t. 63: 1893, s. 1137-1142.

${ }^{46}$ B. Skarżyński : s. 318. 
You ask how I have got on with my experiments on ettylphyllotaonin. Well I am sorry to say. I have not had complete success ${ }^{47}$.

Jak wnosimy z lektury listów Schuncka, śledził on z uwagą całą dostępną mu literaturę naukową pod kątem badań nad barwnikami, informując o swoich spostrzeżeniach i ocenach, nierzadko bardzo krytycznych i zjadliwych pod adresem innych autorów. Najwyraźniej również Marchlewski czynił to samo, przesyłając Schunkowi wraz z korespondencją odbitki i streszczenia prac lub notatki, na które zwrócił uwagę. I tak w liście z dnia 25 maja 1899 r. Schunk, dziękując Marchlewskiemu za przesyłkę, pisze wprost o poglądach głoszonych przez jednego badacza:

The latter I have read though I confess without understanding it. Probably it is not worth any profound study. And in the face of it seems to me all stuff is nonsense. How any man, not being a child or an idiot can, after all that has been done by us and others before us, maintain that chlorophyll remains unchanged after the action of (strong) acids and alkalis passes my comprehension ${ }^{48}$.

W tym samym liście przekazywał również krótką informację o pracach nad ekstraktami alkoholowymi z liści trawy drugorocznego odrostu prowadzonymi przez jednego ze swoich współpracowników, niejakiego Butterfielda (z dużym prawdopodobieństwem chodzi o chemika Johna Cope'a Butterfielda). W ostatnim zdaniu pisze, że niecierpliwie czeka na wyniki badań Marchlewskiego z zastosowaniem nowej metody do przygotowania filotaoniny w roztworze alkoholu etylowego.

Marchlewski, tak należy wnosić z kolejnych listów, na bieżąco informował o własnych doświadczeniach. W odpowiedzi na pismo wysłane prawdopodobnie z końcem maja 1899 r., Schunck odpowiedział 7 czerwca. Już w pierwszym zdaniu znajdował pełne zrozumienie dla zaproponowanej przez Marchlewskiego nowej metody oczyszczenia alkachlorofilu przy pomocy eteru. Jednocześnie informował o tym, że Butterfield postępował przy oczyszczaniu alkachlorofilu w zgodzie z wcześniejszymi wskazówkami Marchlewskiego (być może przesłanej w którymś z listów) z powodzeniem. Schunck znajdował jednak w tym pewną niedogodność, jaką była słaba rozpuszczalność związku sodu formującego się poprzez oddziaływanie $\mathrm{CO}_{2} \mathrm{w}$ alkoholu. Na tym sprawa się kończy. Resztę listu wypełnia parozdaniowa informacja o liście botanika prof. Edwarda Strasburgera (1844-1912), w którym zawiadamiał Schuncka, że nie może przyjąć do druku nowego artykułu o chlorofilu jego i Marchlewskiego autorstwa ${ }^{49}$.

Do korespondencji bywały dołączone nie tylko streszczenia i odbitki prac, lecz również próbki substancji, co było chętnie stosowaną wówczas praktyką. Z taką właśnie sytuacją mamy do czynienia w pierwszym z zachowanych listów z 26 styczna 1899 r., w którym czytamy;

\footnotetext{
${ }^{47}$ Listy Edwarda Schuncka. Zbiory specjalne KHM UJ CM/Teczka prof. L. Marchlewskiego

${ }^{48}$ Tamże.

${ }^{49}$ Tamże.
} 
I forward enclosed a small specimen of the substance formed under unknown conditions on passing $\mathrm{Cl} \mathrm{H}$ [zapis oryginalny] trough [wyraz nieczytelny] of leaves in place of the phylloxanthin and phyllocyanin usually founded. It has been purified but being amorphous it is uncertain whether it is quite pure $e^{50}$.

Jasno z tego widać, że angielski chemik miał nadal sporo pytań i wątpliwości, a znacznie mniej odpowiedzi. Dalej Schunck przyznaje, że poddawał tą substancję działaniu kwasów i zasad, nie uzyskując żadnych konkretnych produktów reakcji. Niewątpliwie był to dowód zaufania, jakim angielski chemik darzył polskiego badacza, licząc, że ten pomoże mu w rozwiązaniu problemu, z którym nie potrafił sobie sam poradzić.

Pomimo stosunkowo niewielkiego dystansu dzielącego Clayton od Kersal nie wydaje się by Schunck i Marchlewski mieli wiele okazji do odwiedzin. Jak wynika z listu datowanego na dzień 7 stycznia 1900 r., Schunck cieszył się z nadchodzącego spotkania w laboratorium w Kersal. Jednocześnie z góry przepraszał za ewentualne spóźnienie, podkreślał, że Butterfield zajmie się wszystkim do czasu jego przybycia. Wspomina o tym, że roztwory (nie podaje jakie i czego) na czas przyjazdu Marchlewskiego będą już gotowe. Wynika z tego, że mieli wspólnie przeprowadzić eksperyment lub serię eksperymentów i Schunck był tym faktem najwyraźniej poruszony ${ }^{51}$.

Rok 1900, jak już zaznaczyliśmy, był w życiu Marchlewskiego przełomowy. Wyjazd polskiego badacza na kontynent i powrót na ziemie polskie powodują, że korespondencja staje się mniej intensywna. Wpływ mają na to zarówno odległość, jaką teraz muszą pokonać listy, a także pogarszający się stan zdrowia Anglika. W piśmie z 7 sierpnia 1900 r. Schunck na samym jego wstępie tłumaczył blisko miesięczną zwłokę w odpowiedzi. Tak o tym pisał:

Your letter of the $10^{\text {th }}$ ult was duly read. I am sure you will excuse delay in replying when

I tell you that I have been far from well and quite unable to write or to do anything but sit still and read a little ${ }^{52}$.

$\mathrm{Na}$ kolejnych stronach wyrażał nadzieję, że droga, którą obrał Marchlewski (najwyraźniej polski badacz musiał podzielić się z Schunckiem swoimi zamierzeniami) w badaniach nad mechanizmem tworzenia się etylofilotaoniny pozwoli ostatecznie wyjaśnić tę kwestię. Nadmienia również, że ucieszyła go propozycja prof. Juliusa Wilhelma Brühla (1850-1911) ${ }^{53}$, który zaproponował Marchlewskiemu napisanie nowego tekstu o chemii chlorofilu. Dalej pisze na temat swoich badań nad indykanem, do których wówczas powracał po latach i o swojej korespondencji oraz przesłanych mu przez profesora Politechniki z Delf Sebastiana

\footnotetext{
${ }^{50}$ Tamże.

${ }^{51}$ Tamże.

${ }^{52}$ Tamże.

${ }^{53}$ Światowej sławy polski fizykochemik zajmujący się spektrometrią. W latach 1880-1884 był profesorem Politechniki Lwowskiej, a od 1888 Uniwersytetu w Heidelbergu.
} 
Hoogewerffa próbek indykanu ${ }^{54}$. Przy tej okazji stwierdzał, że wszelkie wcześniejsze przypuszczenia stawiane przez Marchlewskiego w kierunku badań nad indykanem okazały się zaskakująco trafne.

Ciekawe są spostrzeżenia Schuncka, który porównywał nadesłany mu przez Hoogewerffa krystaliczny indykan ze swoim amorficznym indykanem ${ }^{55}$. Ten ostatni nazwał $\alpha$-indykanem, a produkt krystaliczny $\beta$-indykanem. Porównując rozpuszczalność obu w alkoholu, eterze oraz wodzie Schunck konkludował, że nie ma w tym przypadku znaczących różnic. Natomiast zachowują się one nieco inaczej pod wpływem odczynników chemicznych. Pod wpływem ługów $\alpha$-związek zabarwia się na żółto, a z octanem ołowiu daje żółty osad, $\beta$-związek w podobnych warunkach daje odpowiednio białe zabarwienie i biały osad. Działając stężonym kwasem solnym w obecności utleniacza $\alpha$-indykan daje błękit indygowy (indygotynę), czerwień indygową (indyrubinę) oraz rodzaj cukru, nieidentyczny z glukozą, natomiast $\beta$-związek w podobnych warunkach przekształca się w indygotynę i glukozę. Podobnie były wyraźne różnice $\mathrm{w}$ zachowaniu się $\alpha$-indykanu oraz $\beta$-indykanu poddanych ługowaniu ${ }^{56}$.

O swoich ustaleniach postanowił poinformować Marchlewskiego przesyłając mu razem z listem z dnia 19 października 1900 r. odbitkę swojego doniesienia z „Chemical News” (E. Schunck, Recent researches on Indican, Chemical News, 1900, t. 82, s. 176-177). Jednocześnie stan zdrowia Schuncka wyraźnie się pogorszył. Narzekał, że nie może pracować więcej niż dwie godziny dzienne w laboratorium. Mimo to kontynuował swoje eksperymenty prowadzone na materiale z liści urzetu barwierskiego, co wiązało się ściśle z kontynuacją badań nad indygo. Przy tej okazji wspominał o izatynie, czyli produkcie utleniania barwnika indygo przez kwas azotowy i kwas chromowy, odnosząc się do faktu, że Marchlewski zainteresował się ponownie tą substancją. Jak możemy wnosić z treści listu, Schunck był zainteresowany najnowszymi rezultatami badań Marchlewskiego nad chlorofilem. Pisał m.in. "I suppose you still adhere to the opinion that there is only one chlorophyll in spite of all that has been said to the contrary"57. Na końcu informuje Marchlewskiego, że nie znalazł niczego interesującego w literaturze fachowej, co wiązało by się z badaniami nad chlorofilem.

W kolejnym z zachowanych listów, datowanym na 21 listopada 1900 r., Schunck na samym początku pisze, że posyła gramową próbkę substancji pozyskanej z izatyny i drewna, pisząc równocześnie szczegółowo o kolejnych stopniach jej oczyszczania z użyciem wrzącego fenolu i eteru włącznie. Zwraca także uwagę, że uzyskany w ten sposób produkt rozpuszcza się, gdy jest traktowany wrzącym alkoholem

${ }^{54}$ Hoogewerff w 1880 r. otrzymał kwas antranilowy, z którego otrzymywano w tamtym czasie syntetyczne indygo.

${ }^{55}$ E. S c h u n ck: Recent researches on Indican, „Chemical News” t. 82: 1900, s. 176-177.

${ }^{56} \mathrm{~J}$. Bielecki: s. 21.

${ }^{57}$ Zbiory specjalne KHM UJ CM/Teczka prof. L. Marchlewskiego. 
lub kwasem. W tym drugim przypadku daje w efekcie niebieski lub fioletowy roztwór, lecz po odstawieniu na pewien czas traci całkowicie barwę. Jak zdołał ustalić, w produkcie powyższych reakcji można znaleźć śladowe ilości indyrubiny. I dodaje; "I hope you will be able to make something out"s8.

W jednym z ostatnich zdań nawiązuje do problemu chlorofilu, który, jak pisze jest nadal zagadką. Jest jednocześnie głęboko przeświadczony, że wspólne ich ustalenia w swoich pryncypiach pozostaną niezmienne.

Sprawa badań nad izatyną powraca w kolejnym liście z 10 kwietnia 1901 r., w którym Schunck przepraszał Marchlewskiego za długą przerwę w korespondencji, podkreślając, że na list polskiego badacza z lutego mógł odpowiedzieć dopiero teraz, ponownie usprawiedliwiając się złym stanem zdrowia. Marchlewski musiał pisać Schunckowi o swoich badaniach nad działaniem izatyny w roztworach wodnych urzetu barwierskiego (Isatis tinctoria), które najwyraźniej były na ukończeniu. Wydaje się, że polski badacz przedstawił angielskiemu koledze schemat zachodzących w roztworach reakcji chemicznych, gdyż ten w odpowiedzi stwierdza, że jest to dla niego sprawa całkowicie nowa. Musiało to Schuncka zaintrygować, gdyż przyrzekał Marchlewskiemu, iż powtórzy jego eksperymenty. Równocześnie zobowiązywał się osobno podać dokładny opis własnych metod pozyskiwania substancji, którą posłał w listopadzie $1900 \mathrm{r}$.

Dalej odnosił się do prac Marchlewskiego nad indygo. Pisał:

I look forward with much interest to the continuation of your research on Indican it is sure to lead to important results. All my earlier work was made with Isatis which I always used at that time for preparation of indican ${ }^{59}$.

Pytał, można powiedzieć, w zgodzie z obyczajem, o prace nad chlorofilem, wspominając po raz pierwszy, że sam musi się z tym kierunkiem badań rozstać: „To this too I am afraid, I must now bid final farewell the work has been to me labours of love"60. Schunck pisząc te słowa miał skończone już 80 lat. Nie zmienia to jednak w niczym jego krytycznej oceny prac naukowych innych badaczy. Wspomina bowiem o pracy M. Towetta nad chlorofilem, której streszczenie przeczytał i poszukuje teraz oryginalnego tekstu. Przy tej okazji stwierdza, że z pewnością nie ma drugiego takiego przedmiotu badań jak chlorofil, w którym to przedmiocie napisano by tyle nonsensów. Na koniec, w osobnym akapicie, Schunck pisał:,,I am astonished and pleased to hear that the subject of isatin has proud so prolific in your hands"61.

W kolejnym z listów, datowanym na 8 lipca 1901 r., Schunck gratuluje Marchlewskiemu rozwiązania problemu rozbieżności w wynikach swoich własnych eksperymentów i jak się wyraził „holenderskiego badacza” (może chodzi o Hoogewerffa?)

\footnotetext{
${ }^{58}$ Tamże.

${ }^{59}$ Tamże.

${ }^{60}$ Tamże.

${ }^{61}$ Tamże.
} 
nad działaniem izatyny na ekstrakty z drewna. Co więcej utwierdza się w przekonaniu, że indykan jest substancją o charakterze bardziej „fizjologicznym” niż „chemicznym”. Donosił także o rezultatach doświadczeń z rdestem barwierskim, uzyskując ciekawe efekty w pozyskiwaniu indygo ${ }^{62}$.

Warto może w tym miejscu powiedzieć, że indyrubiną i izatyną interesował się Marchlewski bliżej w początkowym okresie swego pobytu w Krakowie, gdzie wraz z Józefem Buraczewskim i Antonim Korczyńskim doprowadził do otrzymania w drodze syntezy nowego typu związków chemicznych, które nazwał indofenazynami ${ }^{63}$.

Kolejnym ważnym osiągnięciem Marchlewskiego wiążącym się ściśle z problematyką chlorofilu było odkrycie filoerytryny. W 1903 r. zdołał wydzielić z kału krów skarmianych świeżą trawą krystaliczny związek będący produktem przemiany chlorofilu w organizmie zwierząt roślinożernych. Jak ustalił, związek ten powstawał z rozpadu chlorofilu podczas trawienia, nie potrafił jednak wówczas podać jego wzoru strukturalnego. Filoerytryna rozpuszczała się łatwo w substancjach organicznych, a poddana działaniu stężonego kwasu octowego barwiła się na wiśniowo. Dawała również charakterystyczne widma absorpcyjne zbieżne do widma filoporfiryny ${ }^{64}$. I ponownie widzimy zbieżność badań Marchlewskiego z tym, co stanowiło przedmiot zainteresowań naukowych Schuncka.

Jak wynika z listu datowanego na dzień 20 listopada 1901 r. Schunck już wówczas interesował się potencjalnymi przemianami chlorofilu podczas procesu trawienia. Pisał wówczas

The discovery alluded to my son resulted from the work which has occupied me during last summer. My object was to ascertain if any and if so what changes take place in chlorophyll of vegetables in its passage through the bodies of animals. I find that chlorophyll entirely disappears but it is replaced by the products of decomposition, reassembling but not identical with those formed outside the body. One of the products is interesting. It reassembles phyllocyanin - crystallizes in rhombic plates, purplish-blue with brilliant metallic luster $[\ldots]^{65}$.

W dalszej części listu rozpisuje się o możliwościach, jakie daje ten kierunek badań, wyrażając nadzieję, że ożywi to dyskusję wśród chemików i fizjologów. Podkreśla, nie po raz pierwszy, iż poszukiwania prowadzone przez Marchlewskiego w kręgu chlorofilu i jego pochodnych zachowają swoją wartość zarówno dla fizjologii, jak i chemii.

${ }^{62}$ Tamże.

${ }^{63}$ L. Marchlewski, J. Buraczewski: Studyum nad izatyna, „Rozprawy Akademii Umiejętności” A. 39: 1902, s. 264-286; L. Mar chlewski, A. Korc zyński : Studyum nad izatyna, „Rozprawy Akademii Umiejętności” A. 42: 1902, s. 245-260.

${ }^{64} \mathrm{~L}$. March lew ski : $Z$ chemii chlorofilu. O filoerytrynie, „Rozprawy Akademii Umiejętności" A. 43: 1903, s. 435-439.

${ }^{65}$ Zbiory specjalne KMH UJ CM/ Teczka prof. L. Marchlewskiego. 
W tym samym roku ukazało się obszerne doniesienie, w którym Schunck prezentował zarówno metodykę postępowania badawczego, jak i prezentował jego wyniki. Punktem wyjścia był kał krów karmionych świeżą trawą - a zatem ten sam, jaki przyjmie Marchlewski. Angielski badacz działał na kał wrzącym alkoholem, uzyskując zielono-brązowy ekstrakt podatny na reakcję z kwasami. Poddany oczyszczeniu w wodzie i eterze dawał roztwór o żółto-złotej barwie. W badaniu widmowym był zbieżny z pasmami absorpcyjnymi charakterystycznymi dla filoksantyny. Uczony konkludował, że jakkolwiek nie znalazł najmniejszego nawet śladu obecności chlorofilu, to wykazał obecność jednego z produktów jego rozkładu. Próby oczyszczenia tego produktu nie przyniosły zadawalających rezultatów. Niemniej jednak Shunck prowadził także doświadczenia z ekstrahowaniem za pomocą chloroformu, uzyskując z kolei struktury zbieżne z filocjaniną. Porównawczo badał także zwierzęta karmione warzywami (o czym pisał w liście do Marchlewskiego). Idąc za radą profesora Wilkinsa z Owens College przyjął dla odkrytej przez siebie substancji nazwę - scatocjanina ${ }^{66}$.

Trudno przesądzić, nie wiedząc, czy dysponujemy wszystkimi listami pisanymi przez Schuncka do Marchlewskiego i nie mając wglądu w korespondencję zwrotną, który z badaczy zainspirował drugiego. Jedno nie ulega wątpliwości, że przywołana powyżej praca Schuncka jest wcześniejszą w stosunku do tej opublikowanej przez Marchlewskiego. Należy też zaznaczyć, że filoerytryna była innym produktem niż scatocjanina.

Wracając jeszcze do przywołanego powyżej listu Schuncka z listopada $1901 \mathrm{r}$. warto wskazać na kolejny ciekawy wątek. Otóż współpracujący nadal z Schunckiem Butterfield przeprowadził kontrolne eksperymenty powtarzając doświadczenia szwajcarskiego chemika Friedricha Goppelsroedera (1837-1919), które polegały na badaniu chlorofilu w kontekście materiałów pochodzenia roślinnego, takich jak papier czy bawełna. Schuck donosił, że niektóre powstałe w ich wyniku substancje dają znakomity obraz w żółcieni, zieleni i czerwieni ${ }^{67}$.

Goppelsroeder jeszcze jako student w latach 60. XIX wieku opublikował wraz z Christianem Friedrichem Schönbeinem wyniki pierwszych prób badania w modelach eksperymentalnych, w których różne substancje przemieszczają się przez papier filtracyjny. Schönbein uważał, że ruch kapilarny, a nie adsorpcja, był odpowiedzialny za sam proces przemieszczania się, a opis charakterystyki tego ruchu określono mianem techniki analizy kapilarnej. Goppelsroeder niemal całe swoje życie zawodowe spędził nad badaniem szybkości poruszania się różnych substancji w analizie kapilarnej. Jest uważany za prekursora chromatografii bibułowej. Właśnie w 1901 r. opublikował w Bazylei książkę Capillaranalyse: beruhend auf capil-

${ }^{66}$ E. S c h u n ck: Contributions to the Chemistry of Chlorophyll. No. VIII. Changes undergone by Chlorophyll in passing through the Bodies of Animals, „Proceedings of the Royal Society of London" t. 69: 1902, s. 307-312.

${ }^{67}$ Zbiory specjalne KHM UJ CM/Teczka prof. L. Marchlewskiego 
laritäts-und Adsorptionserscheinungen mit dem Schlusskapitel. Była to rzecz nowa i stąd prawdopodobnie zainteresowanie w pracowni Schuncka wykorzystaniem tej metody w badaniach nad chlorofilem.

Kiedy w 1905 r. Marchlewski w pracy zatytułowanej Z postępów badań nad barwnikiem krwi i chlorofilem podsumowywał ówczesny stań badań, Nencki i Schunck już nie żyli. Co się tyczy interesującej nas tutaj szczególnie filoerytryny, to Marchlewski zdołał ostatecznie udowodnić, badając żółć barana karmionego tylko trawą a następnie pokarmem pozbawionym chlorofilu, że jest ona produktem przemiany chlorofilu, nie zaś barwnika krwi. Jednocześnie wykazał, że filoerytryna, wyosobniona z kału krów karmionych wyłącznie świeżą trawą, jest identyczna z bilipurpuryną wyosobnioną przez Wilhelma Franza Loebischa (1839-1912) i M. Fischlera z żółci bydlęcej. Z drugiej strony nie ulegało wątpliwości, że bilipurpuryna jest identyczna z cholehematyną, badaną przez Charlesa Alexandera MacMunna (1852-1911) ${ }^{68}$.

W okresie międzywojennym Marchlewski wycofał się całkowicie z prac nad chlorofilem, poświecił się jedynie analizie widmowej, którą postrzegał jako środek do wyjaśnienia struktury związków organicznych.

Ostatnie listy Schuncka pochodzą z 1902 r. Ich styl jest inny od pozostałych. Przerwy w odpowiedziach na pisma Marchlewskiego są dłuższe. Jak można przypuszczać, bo nie jest to wprost powiedziane, Schunck tracił pamięć i niekiedy po prostu zapominał, że odłożył gdzieś korespondencję. Zmienia się też charakter pisma, który staje się drżący, co najpewniej wynikało z niedowładu dłoni i pogarszającego się wzroku. Sprawy czysto naukowe schodzą na dalszy plan, więcej natomiast spraw osobistych, opinii i pytań.

Z listu datowanego na dzień 19 kwietnia 1902 r. dowiadujemy się, że Marchlewski poszukiwał wsparcia, w tym finansowego, dla swoich badań za granicą, rozważając jakąś formę bliskiej współpracy ze Stanami Zjednoczonymi, czemu dziwi się Schunck, proponując poprzeć starania kolegi na terenie Anglii. Ze spraw dotyczących nauki odnajdujemy jedną, za to ciekawą informację, że Schunck zobowiązuje się wytworzyć większe ilości zmieszanej filocjaniny i filoksantyny, które powinny być gotowe latem tego roku. Można tylko przypuszczać, że przynajmniej część tej „produkcji” była przeznaczona na potrzeby badań Marchlewskiego.

Kolejny zachowany list pochodzi dopiero z jesieni 1902 r. i datowany jest na październik, tym razem po raz pierwszy i ostatni bez daty dziennej. W całości jest poświęcony sprawom prywatnym a Schunck jest wyraźnie przybity, wręcz w depresji. Wypomina swój wiek i dręczące go dolegliwości. Wręcz pisze o tym, że postara się znaleźć jakieś zastępstwo, tak aby Marchlewski miał z kim współpracować stale w Anglii. Tylko w posłowiu pyta czy Marchlewski dostał nieobrobiony produkt rozpadu chlorofilu, który przygotował dla niego i wysłał Butterfield. Na tym posiadana przez nas korespondencja się kończy.

${ }^{68}$ L. Marchlewski: Z postępów badań nad barwnikiem krwi i chlorofilem, „Chemik Polski" R. 5: 1905 nr 41, s. 806. 


\section{Podsumowanie}

Na podstawie zebranego i analizowanego materiału można stwierdzić, że wzajemne relacje pomiędzy Leonem Marchlewskim a Edwardem Schunckiem miały charakter stały i nie zostały przerwane nawet wówczas, kiedy Marchlewski opuścił laboratoria w Kersal w 1897 r., a później również w 1900 r. Anglię. Obaj uczeni byli wyraźnie zainteresowani postępami prac własnych, dzieląc się niemal na bieżąco spostrzeżeniami. Pomimo bardzo dużej różnicy wieku, Schuck był o blisko 50 lat starszy od Marchlewskiego, stosunki pomiędzy nimi były koleżeńskie i serdeczne. Momentami można odnieść nawet wrażenie, że Schunckowi bardzo brakuje obecności polskiego badacza.

Z treści listów wynika, że głównym przedmiotem korespondencji pozostawały $\mathrm{w}$ tych latach dwa wiodące tematy naukowe - chemia chlorofilu i jego pochodnych oraz chemia indygo i pochodnych tej substancji. Natomiast nie znajdujemy u Schuncka żadnych odniesień do współpracy Marchlewskiego z Nenckim. Najwyraźniej nie było to przedmiotem prowadzonych przez nich korespondencji. Natomiast Schunck odnosił się często do wyników uzyskanych przez innych uczonych m.in. Hoogewerffa, Goppelsroedera, Kohla.

Niewątpliwie Schunck, u którego przecież Marchlewski zdobywał swoje pierwsze, jeśli nie liczyć pobytu u Lungego, szlify naukowe, miał duży wpływ na kształtowanie się poglądów i programów badawczych Polaka. Wyraźnie to widać na przykładzie prac Marchlewskiego nad strukturą indykanu i nad izatyną, a także nad produktami rozkładu chlorofilu w procesach trawienia, co doprowadziło do odkrycia filoerytryny. Schunck ze swojej strony musiał wysoko cenić nie tylko wiedzę i talent badawczy Marchlewskiego, lecz również jego zdolności metodyczne, przesyłając mu do analizy te substancje, z którymi nie wiedział co dalej począć. Warto przy tym zwrócić uwagę, że to właśnie w omawianym przez nas okresie życia Marchlewskiego zamykającym się w latach od 1892 r. (początek pracy u Schuncka) do 1904 r. (ostateczne ustalenie natury filoerytryny) polski uczony odnotował swoje największe sukcesy naukowe, znajdując się w ścisłej światowej czołówce badań nad chemią barwników.

\section{WYKAZ LITERATURY}

B a e y e r: Ueber die Verbindungen der Indigogruppe, „Berichte der Deutschen chemischen Gesellschaft zu Berlin" t. 16: 1883;

J. B i el e cki: Chemia indyga i rozwój metod technicznych otrzymywania indyga naturalnego i sztucznego, „Chemik Polski” t. 1: $1901 \mathrm{nr}$ 1;

A. Brod a: Zarys botaniki farmaceutycznej, wyd. VI poprawione, PZWL. Warszawa 2002, s. 283. 
W.V. Fa r ra r: Edward Schunck, F.R.S. A Pioneer of Natural-Product Chemistry, „Notes and Records of the Royal Society of London" t. 31: 1977 nr 2;

R. W. Gry gl e w s ki : Biochemiczna rewolucja, czyli rzecz o Leonie Marchlewskim i Marcelim Nenckim, „Wiadomości Chemiczne” t. 69: 2015 nr 5-6;

J. J. H a z e w in ke l: Indigo - its hydrolysis and the enzyme causing the same, „Royal Netherlands Academy of Arts and Sciences (KNAW) Proceedings" t. 2: 1899-1900;

S. Ho o g e w erff, H. Te r M e u l e n: Contribution to the knowledge of Indican, „Royal Netherlands Academy of Arts and Sciences (KNAW) Proceedings" t. 2: 1899-1900;

T. E. James, T. Travis: Oxford Dictionary of National Biography. [za:] http://www. oxforddnb.com/index/101035974/Edward-Schunck (dostęp: 27.05.2017)

W. Kro s z c zy ń s ki : Krótka historia niektórych wzorów, „Wiadomości Chemiczne” t. 67: 2013, nr 7-8;

L. Marchlewski: The constitution of rubiadinglucoside and rubiadin, „Journal of the Chemical Society Transactions" t. 63: 1893;

L. M a r c h l e w s ki: Z Chemii Chlorofilu (dokończenie), „Wszechświat” t. 14: 1895, nr 20;

L. March lews ki: Indygo, „Wszechświat” t. 17: 1898 nr 37;

L. Ma r ch l e w s ki: $Z$ chemii chlorofilu. O filoerytrynie, „Rozprawy Akademii Umiejętności” A. 43: 1903;

L. M a r c h lews ki: Z postępów badań nad barwnikiem krwi i chlorofilem, „Chemik Polski” R. 5: $1905 \mathrm{nr}$ 41;

L. Marchlewski, J. Bura c zewski: Studyum nad izatyna, „Rozprawy Akademii Umiejętności" A. 39: 1902;

L. M a r ch l e w s ki, A. Ko r c zy ń s ki : Studyum nad izatyna, „,Rozprawy Akademii Umiejętności" A. 42: 1902;

L. Marchlew ski, L. G. Ra d cliffe: Note on the constitution of indican and some derivatives of indigotin. „Journal of the Society of Chemical Industry” t. 17: $1898 \mathrm{nr}$ 5;

L. Marchlews ki, L. G. Rad cliffe: Zur Kentniss des Indigotins. „Journal für practische Chemie" t. 58: $1898 \mathrm{nr}$ 1;

W. Ostrows ki : Leon Marchlewski (1869-1946), „Folia Biologica” t. 14: 1966 nr 4;

W. J. R u s s ell, W. La p r a ik: A spectroscopic study of chlorophyll, „Journal of the Chemical Society, Transactions" t. 41: 1882;

M. S a r n e ka - Kell er, J. H u l e wi cz: Marchlewski Leon Pawet, PSB t. 17: 1974;

E. S chunck: On Rubian and Its Products of Decomposition, „Philosophical Transactions of the Royal Society", t. 143: 1853;

E. Schunck: XXXIV. On the occurrence of indigo-blue in urine, „The London, Edinburgh, and Dublin Philosophical Magazine and Journal of Science", t. 14: 1857;

E. Schunck: On Indigo-blue from Polygonum tinctorium and other Plants, „Chemical News" t. 39: 1879;

E. Schunck: Note on modified Chlorophyll from the leaves of Eucalyptus globulus, „Proceedings of the Manchester Literary and Philosophical Society” t. 19: 1880;

E. Schunck: Contributions to the Chemistry of Chlorophyll, „Proceedings of the Royal Society of London" t. 39: 1885;

E. S chunck: Conributions to the chemistry of chlorophyl. No III, Proceedings of the Royal Society of London t. 44: 1888; 
E. Schunck: Notes on some ancient dyes. "Memoirs and Proceedings of the Manchester Literary and Philosophical Society" t. 5: 1892 Seria 4;

E. S ch un ck: Recent researches on Indican, „Chemical News” t. 82: 1900;

E. S chunck: Contributions to the Chemistry of Chlorophyll. No. VIII. Changes undergone by Chlorophyll in passing through the Bodies of Animals, „Proceedings of the Royal Society of London" t. 69: 1902;

E. S c h u n ck, H. Rö m e r: Ueber die Zersetzung des Pflanzenindicans bei Abschlus der Luft, „Berichte der Deutschen chemischen Gesellschaft” t. 12: 1879;

E. Schunck, L. Marchlewski: Contributions to the Chemistry of Chlorophyll; No. VII. Phylloporphyrin and Haematoporfyrin: Comparision, „Proceedings of the Royal Society of London" t. 94: 1895;

I. Z. Si e mi o n : Notatki Chaotyczne, „Wiadomości Chemiczne” t. 57: 2004 nr 7-8;

F. E. S h e i b l ey: Carl Julius Fritzsche and the discovery of anthranilic acid, 1841, „Journal of Chemical Education" t. 20: $1943 \mathrm{nr}$ 3;

B. S karżyń s ki,:Leon Marchlewski (1869-1946), [w:] „Sześćsetlecie medycyny krakowskiej" pod red. L. To c how i c za, Kraków 1963, t. 1;

Zbiory specjalne KHM UJ CM/Teczka prof. L. Marchlewskiego 